Acta vet. scand. $1989,30,441-445$.

\title{
Plasma Lipids in Normal Cows around Partus and in Cows with Metabolic Disorders with and without Fatty Liver
}

\author{
By Paul Holtenius
}

Department of Cattle and Sheep Diseases, Swedish University of Agricultural Sciences, Uppsala.

\begin{abstract}
Holtenius, P.: Plasma lipids in normal cows around partus and in cows with metabolic disorders with and without fatty liver. Acta vet. scand. 1989, 30, 441-445. Free fatty acids, cholesterol and phospholipids in plasma were studied from 6 weeks before to 6 weeks after calving in 16 normal multiparous cows. The same plasma lipids were studied the day after calving in 20 normal primiparous cows. Ten of these were fed according to standards and the other 10 were overfed the last 3 weeks prepartum.

The plasma lipids were also analysed in 16 cows with left displacement of the abomasum and fatty liver, and in 16 cows with ketosis with no or only slight fat infiltation of the liver.

In the normal cows there was a rise in FFA-level and a reduction in cholesterol and phospholipids from 6 weeks before to the day after calving. Thereafter there was a reduction of FFA-level and rise in cholesterol and phospholipids.

Increased feed intensity had no effect on plasma lipids at calving. The level of the plasma lipids in cows with fatty liver differed very much from the amounts in normal cows at corresponding time from calving. Cows with ketosis had high FFA-level but the amount of cholesterol and phospholipids differed very little from normal cows.
\end{abstract}

free fatty acids; cholesterol; phospholıpids; feeding; calving; ketosis.

\section{Introduction}

In ruminants almost no plasma lipids arise from ingested fat. Most of them are the result of de novo synthesis.

Fat is stored as triglycerides and from the depots it is transported as free fatty acids bound to albumen. A considerable part of these acids is taken up by the liver. There they can be oxidized to $\mathrm{CO}_{2}$ or to ketone bodies or esterified and combined with phospholipids, cholesterol and apoproteins to form lipoproteins, mainly very low density lipoprotein (VLDL). This lipoprotein fraction transports triglycerides to different organs and tissues. After the loss of triglycerides low density lipoproteins (LDL) are formed and after further metabolism high density lipoproteins (HDL).
In cattle HDL is the major fraction comprising more than $80 \%$ of the lipoproteins (Ferreri \& Gleockler 1979, Holtenius \& Hjort 1988 ) and consisting of about $60 \%$ cholesterol (Raphael et al. 1973). As the feed for cattle contains very small amounts of cholesterol and there is high level of this substance in plasma, there must be an important synthesis in the body. Cholesterol can be synthetized in the liver from acetate (Bell 1980) and it is probably by this way the cholesterol in the VLDL-fraction is formed. It is not known if a de novo synthesis of HDL occurs in the liver in cattle.

There are large variations in the fat metabolism during different stages of lactation and pregnancy and the risks of disturbances are also variable. The intention of the present 
investigation was to elucidate the pathogenesis of fatty liver in cows by studying the influence of feeding, pregnancy and beginning of lactation on plasma lipids in normal cows and also by investigating plasma lipids in cows with fatty liver and in cows with ketosis without or with only slight fat infiltration in the liver cells.

\section{Material and methods}

Sixteen normal multiparous Swedish Red and White cows with an average milk yield of $7900 \mathrm{~kg} \mathrm{FCM} /$ year were studied from 6 weeks before to 6 weeks after calving. Twenty normal primiparous cows of the same breed were examined on the day after calving. Besides these normal animals 20 cows with left displacement of the abomasum (LDA) and fatty liver and 16 cows with ketosis without or with only slight fat infiltration in the liver were examined. The cows with LDA had been sent to the clinic for treatment, and the cows with ketosis were examined on the farms.

The normal multiparous cows were fed hay, $1.5 \mathrm{~kg} \mathrm{DM}$ and silage $6.5 \mathrm{~kg} \mathrm{DM}$ and concentrates according to Swedish standards. The first-calving cows were divided in 2 similar groups and all animals were given the same amount of roughage as the older cows, but the amount of concentrates was different. From 3 weeks before calving it was increased gradually up to $3 \mathrm{~kg}$ in one group and to $7 \mathrm{~kg}$ in the other group at calving. The concentrate was given at 8 a.m. and 2 p.m.

In all normal cows blood samples were taken in the jugular vein at 1 p.m. $5 \mathrm{~h}$ after the morning feeding and before the afternoon feeding. In the multiparous cows samples were taken every second week from 6 weeks before to 6 weeks after calving and on the day after calving. In the first calving cows samples were taken on the day after calving. Samples from cows with LDA and fatty liver were taken 1 day after the arrival to the clinic and in the cows with ketosis sampling was done in connection with the examination of the animal at the farm. After sampling plasma was stored at $-20^{\circ} \mathrm{C}$ until analysed. In all animals fine needle liver biopsy was performed for diagnosing fatty liver (Holtenius 1961, Holtenius \& Niskanen 1985).

Free fatty acids, cholesterol and phospholipids were determined by commercial enzymatic kits, NEFA C-test Wako Industries, Osaka, Japan, for free fatty acids and Boehringer Mannhein Diagnostica for phospholipids and cholesterol.

\section{Results}

The results from the study of plasma lipids in 16 normal cows around calving are presented in Fig. 1. From 6 weeks to 2 weeks before calving there was a slight increase in FFA from $0.13 \pm 0.05$ to $0.17 \pm 0.04$ $\mathrm{mmol} / \mathrm{l}$. Then there was a sharp rise to the day after calving when the level was $0.54 \pm$ $0.44 \mathrm{mmol} / \mathrm{l}$. Two weeks thereafter the level had dropped to $0.36 \pm 0.17 \mathrm{mmol} / \mathrm{l}$ and after 4 weeks to $0.30 \pm 0.17 \mathrm{mmol} / 1$ and after 6 weeks the amount was $0.26 \pm 0.11 \mathrm{mmol} / 1$.

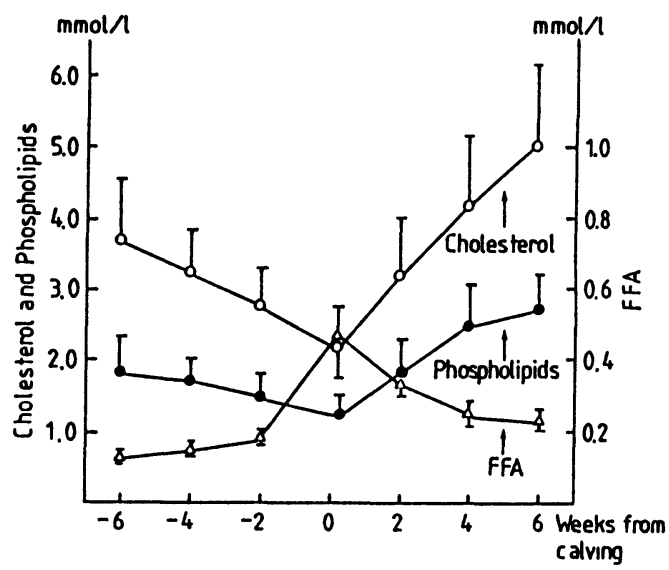

Figure 1. Plasma lipids in 16 normal cows from 6 weeks before to 6 weeks after calving. 
The plasma cholesterol values dropped gradually from 6 weeks before to the day after calving from $3.69 \pm 0.87 \mathrm{mmol} / \mathrm{l}$ to $2.20 \pm 0.42 \mathrm{mmol} / \mathrm{l}$. During the following 6 weeks the level increased continuously to $4.98 \pm 1.11 \mathrm{mmol} / \mathrm{l}$. Also the phospholipid values dropped from 6 weeks before to minimum level the day after calving. The values were $1.83 \pm 0.49$ and $1.24 \pm 0.24 \mathrm{mmol} / \mathrm{l}$ re-

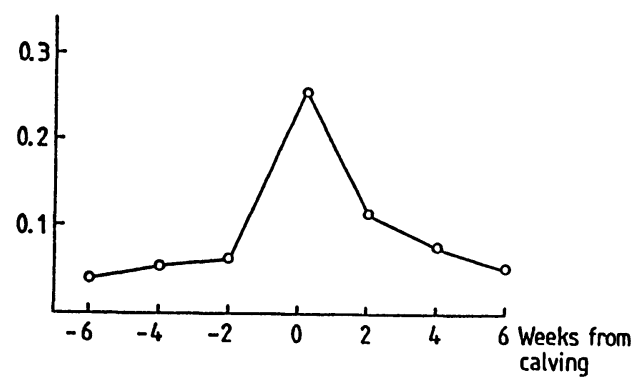

Figure 2. Free fatty acid/cholesterol ratio in 16 normal cows from 6 weeks before to 6 weeks after calving. spectively. Then the amount increased and was $2.67 \pm 0.50 \mathrm{mmol} / 16$ weeks after calving.

There was a strong rise in the FFA/cholesterol ratio from 2 weeks before to the day after calving and a drop thereafter (Fig. 2). The changes in the parameters from 6 weeks before to calving and from calving to 6 weeks later are all significant $(\mathrm{p}<0.01)$.

The results from the study of plasma lipids in first calving cows are presented in Table 1. The level of free fatty acids the day after calving is lower in these animals than in the older cows. The high feeding intensity had no effect on the plasma lipids. They were very similar in both groups.

The level of the plasma lipids in cows with fatty liver differed very much from the amounts in normal animals at corresponding time from calving (Table 2). The cows with fatty liver had higher level of FFA, lower amounts of cholesterol and phospholi-

Table 1. Plasma lipids the day after calving in primiparous cows on two different feed (mean \pm S.D.).

\begin{tabular}{lrc}
\hline Number of animals & 10 & 10 \\
Roughage Kg DM & 8 & 8 \\
Concentrates kg & 3 & 7 \\
Metabolizable energy MJ & 120 & 160 \\
Digestible crude protein g & 1200 & 1800 \\
Free fatty acids mmol/1 & $0.34 \pm 0.13$ & $0.34 \pm 0.15$ \\
Cholesterol mmol/1 & $2.64 \pm 0.67$ & $2.69 \pm 0.57$ \\
Phospholipids mmol/1 & $1.59 \pm 0.42$ & $1.67 \pm 0.26$ \\
\hline
\end{tabular}

Table 2. Plasma lipids in cows with LDA and moderate-severe fatty liver and in cows with ketosis and no or slight fatty liver compared with normal cows in corresponding time after calving (mean \pm S.D.).

\begin{tabular}{lcccccc}
\hline & $\begin{array}{c}\text { Number } \\
\text { of cows }\end{array}$ & $\begin{array}{c}\text { Weeks after } \\
\text { calving }\end{array}$ & $\begin{array}{c}\text { FFA } \\
\mathrm{mmol} / 1\end{array}$ & $\begin{array}{c}\text { Cholesterol } \\
\mathrm{mmol} / 1\end{array}$ & $\begin{array}{c}\text { Phospholipid } \\
\mathrm{mmol} / 1\end{array}$ & $\begin{array}{c}\text { FFA/ } \\
\text { Cholesterol }\end{array}$ \\
\hline $\begin{array}{l}\text { Cows with LDA } \\
\text { and fatty liver }\end{array}$ & 20 & $3-5$ & $1.26 \pm 0.43$ & $2.16 \pm 0.97$ & $1.15 \pm 0.43$ & 0.58 \\
$\begin{array}{l}\text { Normal cows } \\
\text { Cows with }\end{array}$ & 16 & 4 & $0.30 \pm 0.17$ & $4.18 \pm 1.06$ & $2.46 \pm 0.55$ & 0.12 \\
ketosis & 16 & $4-8$ & $0.98 \pm 0.57$ & $4.02 \pm 1.62$ & $2.15 \pm 0.83$ & 0.24 \\
Normal cows & 16 & 6 & $0.26 \pm 0.11$ & $4.98 \pm 1.11$ & $2.67 \pm 0.50$ & 0.05 \\
\hline
\end{tabular}


pids and higher FFA/cholesterol ratio. The level of FFA was also higher in cows with ketosis than in normal animals but the differences in cholesterol and phospholipids were very small.

\section{Discussion}

During the period around calving there are big changes in the level of plasma lipids. In spite of increased feeding intensity in the last weeks before calving there is a strong rise in the FFA-level. The experiment with one very high and one moderate feeding intensity to first calving cows shows, that the rise in FFA is not inhibited by increased feeding. There are many reports on fat metabolism during the end of pregnancy and the post parturient period especially in laboratory animals but also in cows (McNamara \& Hillers 1986). There is no doubt that the change of the fat metabolism is initiated by pregnancy and lactogenic hormones. Several investigators have emphasized the importance of prolactin in this connection (Bauman \& Currie 1980, Agius et al. 1979, Zinder et al. 1974). Influence of reduced progesterone activity on lipoprotein lipase activity has been studied by Spooner et al. 1977, and on the number of insulin receptors in adipose tissue by Vernon et al. 1981.

There are two main reasons for increased lipolysis in adipose tissue and rised level of free fatty acids in plasma, the hormonally induced at partus and lack of energy in the feed. In both these cases there is increased transport of fatty acids to the liver and increased demand for capacity to eliminate them. There are also two main ways for elimination namely esterification to triglycerides to form a part in lipoprotein or oxidation to ketone bodies, the choice of which will depend on the glucose metabolism. If there is increased fatty acid transport to the liver and the elimination is reduced, the result will be accumulation of triglycerides in the cells. The present investigation shows that the cows with fatty liver had very high plasma FFA-level and low amounts of cholesterol and phospholipids. This indicates that the synthesis of lipoproteins is reduced. As FFA are lipids on the way to the liver and cholesterol has left the liver, the FFA/cholesterol ratio can be used as an expression of fat retained or metabolised in the organ. The high ratio in the cows with fatty liver is in accordance with this.

The cows with ketosis also had high plasma FFA-level but almost normal amounts of cholesterol and phospholipids and no or only slight fat infiltration of the liver cells. Thus the synthesis of lipoproteins was reduced only to a very small degree. The increased FFA/cholesterol ratio is caused by the oxidation of fatty acids to ketone bodies. Esterification of fatty acids to triglycerides and oxidation to ketones are two quite reverse reactions, and the results from the present investigation are in agreement with this.

The studies also show that accumulation of fat in the liver cells and development of fatty liver is caused by reduced synthesis of very low density lipoprotein, VLDL. The reduced synthesis is most probably associated with feeding factors. High energy - low protein prepartum feeding is shown to be such a factor (Holtenius \& Hjort 1988). One possibility is that this feeding leeds to lack of apoprotein, but lack of cholesterol can not be excluded as a causal factor. High grain feeding resulting in low acetate/propionate ratio in the rumen may reduce the possibilities for cholesterol synthesis in the liver. 


\section{References}

Aglus L, Robinson AM, Girard JR, Williamson DH: Alterations in rate of lipogenesis in vivo in maternal liver and adipose tissue on premature weaning of lactating rats. Biochem. J. 1979, 180, 689-692.

Bauman DE, Currie WB: Partitioning of nutrients durıng pregnancy and lactation: A review of mechanisms involving homeostatis and homeorhesis. J. Dairy Sc1. 1980, 63, 1514-1529.

Bell $A W$ : Lipıd metabolısm in liver and selected tissues and in the whole body of ruminant anımals. Proc. Lipid Res. 1980, 18, 117-164.

Ferrerı LF, Gleockler DH: Electrophoretic characterization of bovine lipoprotein subfractions isolated by agarose gel chromatography. J. Dairy Sci. 1979, 62, 1577-1582.

Holtenius P: Cytological puncture: A new method for the study of bovine hepatic disease. Cornell Vet. 1961, 50, 56-63.

Holtenius $P$, HJort M: Studies on the pathogenesis of fatty liver in cows. Proc. XV World Buiatric Congress 1988, 214-220.

Holtenius $P$, Niskanen $R$ : Leberzellverfettung bei Kuhen mit Labmagenverlagerung. (Fatty changes of the liver cells in cows with abomasal displacement). Dtsch. Tierarzl. Wschr. 1985, 92, 398400.

McNamara JP, Hillers JK: Adaptations in lipid metabolism of bovine adıpose tissue in lactogenesis and lactation. J. Lipid Res. 1986, 27, 150-157.

Raphael BC, Dimick PS, Puppione DL: Lipıd characterization of bovine serum lipoproteins throughout gestation and lactation. J. Dairy Sci. 1973, 56, 1025-1032.

Spooner PM, Garrison MM, Scow RO: Regulation of mammary and adipose tissue lipoprotein lipase and blood triacylglycerol in rats during late pregnancy. Effect of prostaglandins. J. clin. Invest. $1977,60,702-708$.
Vernon RG, Clegg RA, Flint DJ: Metabolism of sheep adipose tissue during pregnancy and lactation. Adaptation and regulation. Biochem. J. 1981, 200, 307-314.

Zinder O, Hamosh M, Fleck C, Scow R: Effect of prolactın on lipoprotein lipase in mammary gland and adipose tissue of rats. Amer. J. Physiol. 1974, 226, 744-748.

\section{Sammanfattning \\ Plasmalipider hos normala kor runt partus och hos kor med amnesomsattningsrubbningar med och utan leverforfettning. \\ Fria fettsyror, kolesterol och fosfolipider i plasma studerades från 6 veckor fore till 6 veckor efter par- tus hos 16 hogproducerande normala kor, som kal- vat mer an en gång. Samma plasmalipider studera- des dagen efter kalvningen på 20 normala forsta- kalvskvigor av vilka 10 fått normal utfodring och 10 overutfodrats fram til partus. \\ Plasmalıpiderna undersoktes också på 16 kor med vanstersidig lopmagsforskjutning och leverforfett- ning och på 16 kor med acetonami och ingen eller en- dast ringgradig leverforfettning. \\ Hos de normala korna steg mangden fria fettsyror fram till kalvningen och sjonk darefter. Kolesterol och fosfolipider sjonk fram till kalvningen och steg darefter. FFA/kolesterolkvoten steg och var hogst dagen efter kalvningen. \\ Det var ingen skıllnad 1 plasmalipıder mellan de båda grupperna forstakalvskvigor. Den kraftigt okade fo- dertillforseln påverkade inte stegringen av FFA. \\ Hos kor med leverforfettning avvek mangderna av de olika plasmalıpıderna mycket tydligt från koncen- trationen hos friska kor vid motsvarande tidpunkt efter kalvningen. \\ Kor med acetonami hade hogre mangd FFA an nor- mala kor men betraffande kolesterol och fosfolipi- der var skillnaderna mycket små.}

(Accepted February 9, 1989).

Reprints may be requested from: Paul Holtenius, Dept. of Cattle and Sheep Diseases, Swedish University of Agricultural Sciences, P. O. Box 7019, S-75007 Uppsala, Sweden. 
